This PDF is a selection from an out-of-print volume from the National Bureau of Economic Research

Volume Title: Tax Policy and the Economy, Volume 14

Volume Author/Editor: James M. Poterba, editor

Volume Publisher: MIT Press

Volume ISBN: 0-262-66164-0

Volume URL: http://www.nber.org/books/pote00-2

Publication Date: January 2000

Chapter Title: Internet Commerce, Tax Sensitivity, and the Generation Gap

Chapter Author: Austan Goolsbee

Chapter URL: http://www.nber.org/chapters/c10846

Chapter pages in book: (p. 45 - 66) 


\section{Internet Commerce, Tax Sensitivity, and The Generation Gap}

\section{Austan Goolsbee}

University of Chicago, G.S.B., American Bar Foundation, and NBER

\section{EXECUTIVE SUMMARY}

This paper uses two major surveys of Internet users in late 1997 and late 1998 to examine the sensitivity of Internet commerce to tax rates. Earlier work has suggested that Internet sales are highly sensitive to local tax rates. This paper documents that new users in both samples show little sensitivity to tax rates. Overall sensitivities to tax rates are not falling, however, despite the rapidly increasing numbers of new users, because as new users (particularly young ones) gain experience, their tax sensitivity appears to rise substantially. Internet commerce as a whole continues to be highly sensitive to tax rates and would fall significantly if existing sales taxes were enforced online.

\section{INTRODUCTION}

The growth of the Internet in the last few years has astounded even the most jaded analyst of the "new" economy. Leading market research firms have predicted that business-to-consumer retail commerce over the Internet, though amounting to almost nothing as late as 1995, will continue to grow at an astounding pace and may exceed $\$ 100$ billion by 2003 (McQuivey et al., 1998).

I wish to thank Peter Klenow, Steven Levitt, and James Poterba for helpful comments. 
Existing sales-tax law treats goods sold over the Internet the same way it treats goods sold from catalog companies: no sales tax is collected from companies that have no physical presence (known as nexus) in the state. Technically, the transactions are not tax-free-every state requires consumers to pay a use tax (at the sales-tax rate) for any out-of-state catalog or Internet purchases. Noncompliance is extremely widespread, however, because states must rely on consumers to volunteer tax payments on their out-of-state transactions. ${ }^{1}$

Since sales taxes make up the largest source of tax revenue for state governments, it is easy to understand why state policymakers are extremely concerned about the implications for their tax base of annual Internet growth rates in excess of 200 percent. $^{2}$ Politicians and advocates on both sides have vehemently debated the tax treatment of the Internet (see Graham, 1999; Smith, 1999; Wyden, 1998; Andal, 1997; Stephenson and Zeisser, 1998). The National Governors Association has called for immediate enforcement of existing sales taxes. Opponents in Congress have passed the Internet Tax Freedom Act (though it does not deal with the sales-tax issue directly). ${ }^{3}$ The topic continues to be heavily debated in policy circles. Indeed, State Tax Notes has declared the issue of taxes and electronic commerce to be "the hottest topic in multistate taxation" (Sheppard, 1998).

Despite the policy interest in the subject, there has been relatively little academic work on the impact that taxes have on Internet commerce. This is probably due to the lack of available data on the subject. This paper will turn to an extensive data source about online retail commerce to evaluate the effect of taxes on Internet commerce and discuss the emerging literature on the subject. Earlier work has suggested that Internet sales are highly sensitive to local tax rates. Since the Internet is

1 The Supreme Court has ruled that out-of-state vendors without nexus cannot be required to collect the use tax [National Bellas Hess, 386 U.S. 753, 1967; Quill, 504 U.S. 298, 1992], so governments must rely on consumer self-reporting.

2 Discussions of the dilemmas facing state government can be found in Newman (1995), Graham (1999), and the Economist (1997). Goolsbee and Zittrain (1999) provide direct evidence of the revenue-loss estimates.

${ }^{3}$ The Internet Tax Freedom Act (ITFA) placed a moratorium on new taxes on the Internet. The ITFA did not restrict right of states to apply sales and use taxes to online commerce (these are not, after all, new taxes). Instead, it primarily prevented states from applying new taxes to Internet access. Though the ITFA itself did not change the sales-tax status quo, it did lead to the creation of the Advisory Commission on Electronic Commerce called upon to give recommendations about how the tax system should treat online commerce. The panel's work is taken seriously enough that the National Association of Counties and United States Conference of Mayors, fearing that the panel was stacked against local governments, initially filed suit to prevent the advisory commission created by the ITFA from meeting to draft recommendations. 
changing so rapidly, however, this paper examines whether the impact of taxes is changing as the composition of Internet users changes. The results suggest that new users show very little tax sensitivity. The results also show, however, that the overall sensitivity of online commerce is not falling by much as time passes, because as users, particularly young users, gain more experience with the Internet and learn about the tax code, their sensitivity to tax rates rises substantially.

The paper will proceed in seven sections. Section 2 will review the existing literature on taxes and the Internet. Section 3 will describe the data and the statistical method of the paper. Section 4 will present an overview of Internet customers and how they are changing over time. Section 5 will present the basic results examining the tax sensitivity of commerce in different time periods. Section 6 will examine the differential tax responsiveness of different types of users over time. Section 7 concludes.

\section{LITERATURE ABOUT THE INTERNET}

Most of the existing academic literature on the subject of Internet taxes has been conceptual discussions and legal analyses. Examples of this work include Fox and Murray (1997), Hellerstein (1997a, 1997b, 1997c), Horner and Owens (1996), McLure (1997, 1998, 1999), Murray (1997), and Steele and Hellerstein (1994). This work has tended to emphasize the importance of neutrality for different types of commerce.

Empirical work has been much more difficult because of the lack of data. There was early work on the effect of prices on the Internet as discussed in Mackie-Mason and Varian (1995) and in McKnight and Bailey (1997), and there has been work looking at price differences for specific types of products (Brynjolfsson and Smith, 1999). The only work on Internet commerce at the individual level is Goolsbee (2000) and Goolsbee and Zittrain (1999).

In Goolsbee (2000), I argue that the increasing prevalence of the Internet is similar to moving everyone with a computer to a geographic border, so we might expect the price elasticity to be high. Economists have long argued that consumer sensitivity to tax rates will be larger for people living along geographic borders or in an open economy where the cost of arbitraging tax rates across locations is low, and that this can have important implications for tax policy (Gordon, 1983; Mintz and Tulkens, 1986; Braid, 1987; Kanbur and Keen, 1993; Trandel, 1992, 1994; Gordon and Neilsen, 1997. Empirical work on the tax response in border communities has tended to confirm these predictions by finding large elasticities. Empirical work on taxes (and other policies) along state bor- 
ders can be found in Mikesell (1970), Fox (1986), Walsh and Jones (1988), Rappaport (1994), and Holmes (1998).

To estimate the online tax sensitivity in Goolsbee (2000), I use a major survey of consumer online purchase patterns from December of 1997 and match it to data on tax rates. The results show that, controlling for a person's observables, people living in high-tax areas are significantly more likely to buy things online. This is equally true within region, within state, and within metropolitan area. Controlling for the frequency with which the individual goes online does not change the result, and the results suggest that this is not due to spurious correlation of tax rates and technological sophistication. People in high-tax areas buy more online, but they do not use the Internet more frequently, do not have more experience with computers, are not more likely to have Internet access, and do not own more consumer electronics than comparable people in other areas. Further, the effect of taxes on Internet commerce appears to be greatest for online products, that, a priori, are most likely to save the buyer from paying sales tax. The estimated elasticities suggest that applying existing sales taxes to the Internet could reduce online sales by up to $25 \%$.

This large effect motivates the current work. Although the previous work mentioned above suggests a high price sensitivity, the fact that taxes do not seem to influence Internet adoption rates suggests that the overall tax sensitivity of Internet commerce may fall rapidly if new users differ from existing ones. With the number of online buyers almost doubling every year, if new users are less price-sensitive, the role of taxes may disappear quickly. Documenting and understanding the dynamics of consumers' online tax sensitivity is the goal of the current paper. The results will show that the tax sensitivities of individuals can change over time as they learn about the tax code.

\section{DATA AND STATISTICAL METHOD}

\subsection{Data}

As mentioned before, a major problem preventing empirical work on Internet commerce has been the lack of data. Aggregate data are problematic because of unobserved individual factors. In this paper, I will revisit the extensive proprietary survey conducted in December 1997 for Forrester Research, one of the leading market research firms on the information economy. As described in more detail in the data appendix, this was a nationally representative survey of more than 110,000 U.S. households, and it includes detailed information about various demo- 
graphic characteristics such as income, age, gender, and so on, as well as the state and metropolitan area of residence. ${ }^{4}$ The survey also covers computer ownership, online access, and whether the individual has ever bought something online. I will also be using the Forrester survey from the next year, conducted in December of 1998, to examine the dynamics of consumer tax sensitivity. The sample size in it is a bit smaller (about 85,000 U.S. households), but most of the relevant questions are the same in the two.

Using the measure of whether the individual has bought something online as the dependent variable, I match each person to the local sales tax rate in their location to determine if tax rates seem to matter for their buying decisions. The method for matching people to tax rates requires some assumptions and is described in the appendix.

\subsection{Model and Specification}

The idea of the paper is that an individual choosing whether to buy a good at a store or online will compare the prices. Assuming that he avoids paying use tax on the online transaction and that local sales taxes do not affect local retail prices (i.e., elastic local supply), the individual will be more likely to buy something online the greater is the relative price ratio $P_{s}(1+t) / P_{I}$, where the $t$ is the sales tax, $P$ is price, and the subscript $S$ indicates in a retail store and $I$ indicates an Internet merchant. ${ }^{5} \mathrm{I}$ follow the common assumption in the literature on sales taxes and assume the price ratio $P_{S} / P_{I}$ is constant across locations, though the results did not change when I controlled for local price levels in Goolsbee $(2000){ }^{6}$

Clearly, identifying a role of the taxed-price ratio does not imply that taxes are the only or even the most influential factor in online decisions. Convenience, time saving, and enhanced selection may weigh in favor of buying online, while shipping costs, the inability to see or try on the product, and security concerns may weigh against it. No matter what

\footnotetext{
${ }^{4}$ The metropolitan areas are actually defined by television markets. These are generally larger than the corresponding SMSAs. San Francisco, for example, includes the entire bay area.

${ }^{5}$ Poterba (1996) and Besley and Rosen (1999) examine the impact of sales taxes on local prices.

${ }^{6}$ Studies that compare Internet and retail prices have yielded differing results. Goldman Sachs (1997) found a ratio close to one. Bailey (1998) found prices, including shipping costs, often higher on the Internet. A more recent estimate on the relative prices of books and $C D$ s indicates that prices on the Internet are about 9-16 percent lower than in stores but that there is considerable online price dispersion (Brynjolfsson and Smith, 1999). I will assume a ratio of one for simplicity.
} 
the relative benefits, these should be in the constant term across locations. Moving from a low-tax to a high-tax location does not change the convenience factor or the inability to sample the product. It only affects the relative price of store versus Internet merchandise.

I will use a linear probability model for the $\{0,1\}$ variable of whether the individual has ever bought something online as a function of the sales-tax rate and a number of economic and demographic controls such as income, age, and education. A probit gave similar results. I will also break up the sample into different types of people to determine if some are more tax-sensitive than others. The data are two independent crosssections, not a panel, so I cannot control for individual fixed effects but I will attempt to use them as a pseudo-panel by comparing the same types of people over time.

TABLE 1

The Size of Internet Retail Commerce (in Millions of Dollars)

\begin{tabular}{lrrr}
\hline & 1998 & 1999 & 2000 \\
\hline Total U.S. Revenue & 7,826 & 18,152 & 33,029 \\
Software & 665 & 1,147 & 1,720 \\
Books & 630 & 1,166 & 1,749 \\
Music & 187 & 374 & 711 \\
Videos & 151 & 301 & 475 \\
Event tickets & 115 & 238 & 476 \\
& & & \\
Apparel & 530 & 1,340 & 2,843 \\
Flowers & 212 & 374 & 510 \\
Greetings & 36 & 68 & 109 \\
Specialty gifts & 63 & 121 & \\
& & & 299 \\
Toys & 68 & 158 & 294 \\
Sporting goods & 56 & 137 & 251 \\
Tools and garden & 63 & 139 & 13,950 \\
Travel & & & 4,147 \\
Computer hardware & 3,073 & 7,798 & 977 \\
Consumer electronics & 1,090 & 411 & 318 \\
& 84 & 118 & 664 \\
Appliances & & 319 & 1,132 \\
Household goods & 17 & 513 & 1,189 \\
Food \& beverage & 83 & 509 & 1,024 \\
Health and beauty & 235 & 517 & \\
Misc. & 213 & &
\end{tabular}

Source: Forrester Research. 
TABLE 2

Summary Statistics of Internet Users ${ }^{(a)}$

\begin{tabular}{lcccc}
\hline & $\begin{array}{c}\text { All Online } \\
\text { Users } \\
\text { Dec. 1997 }\end{array}$ & $\begin{array}{c}\text { Buyers } \\
\text { Dec. 1997 }\end{array}$ & $\begin{array}{c}\text { All Online } \\
\text { Users } \\
\text { Dec. 1998 }\end{array}$ & $\begin{array}{c}\text { Buyers } \\
\text { Dec. 1998 }\end{array}$ \\
\hline$N$ & 26,135 & 5,525 & 37,251 & 16,471 \\
Income & $56.9(33.3)$ & $60.6(33.6)$ & $63.8(32.0)$ & $65.4(32.9)$ \\
Education & $14.8(2.25)$ & $15.2(2.2)$ & $14.9(2.3)$ & $15.1(2.2)$ \\
Age & $40.1(12.5)$ & $39.3(11.9)$ & $43.1(12.2)$ & $42.0(11.8)$ \\
Female & $.55(.50)$ & $.65(.48)$ & $.54(.50)$ & $.59(.49)$ \\
Single & $.40(.50)$ & $.43(.50)$ & $.33(.47)$ & $.37(.48)$ \\
Children & $.41(.49)$ & $.36(.48)$ & $.40(.49)$ & $.38(.49)$ \\
Asian & $.02(.14)$ & $.03(.16)$ & $.02(.14)$ & $.02(.16)$ \\
Other nonwhite & $.15(.35)$ & $.14(.34)$ & $.13(.33)$ & $.12(.33)$ \\
Computer at work & $.78(.41)$ & $.84(.37)$ & $.77(.42)$ & $.81(.39)$ \\
Home business & $.17(.38)$ & $.21(.41)$ & $.20(.40)$ & $.23(.42)$ \\
Have bought online & $.21(.42)$ & $1.0(0)$ & $.44(.47)$ & $1.0(0)$ \\
\hline
\end{tabular}

Source: Author's calculations using data from Forrester Research.

(a) Standard deviations in parentheses.

\section{THE STATE OF THE INTERNET}

To start, I present some descriptive statistics using data from Forrester Research to convey the nature of Internet commerce and how it has changed. ${ }^{7}$ Table 1 presents some data on the overall size of online retail commerce as well as the size of particular subgroups in 1998 along with predictions for 1999 and 2000. The data suggest that from 1998, online retail commerce will grow about $131 \%$ by 1999 and another $80 \%$ the following year. By 2000 this is projected to be more than $\$ 30$ billion of sales. These data do not include financial products such as stocks and insurance.

In Table 2, I present summary statistics from the two surveys for the average online user and for the average online buyer in the samples. The typical Internet user, listed in columns 1 and 3, has high income and education with an average age of about 40 and overwhelmingly uses a computer at work. The characteristics do not seem very different across years. The typical person that has bought something online, listed in columns 2 and 4, is, as might be expected, slightly richer, better edu-

7 This analysis is meant only to give a brief overview for purposes of understanding taxes and the Internet. For anyone wishing to understand the Internet economy in more detail, I recommend reading issues of the Forrester Report that give in-depth coverage of many specific issues regarding the information economy and Internet customers. 
cated, and younger. From late 1997 to late 1998, the share of users actually buying online increased significantly.

\section{DO TAXES MATTER?}

\subsection{Basic Evidence}

The question then is whether taxes matter for Internet commerce and whether this has changed over time. I begin in column (1) of Table 3 with a standard regression for December 1997 as in Goolsbee (2000). I report only the tax coefficient for simplicity [coefficients on all the other variables for this regression can be found in column (1) of Table 9 in the appendix]. The coefficient on one plus the sales tax rate is positive and significant, indicating that the higher is the sales tax, the more likely is the individual online user to have bought something online (controlling for the individual's observable characteristics). The coefficient suggests that the elasticity of Internet commerce is 2.4.

In columns (2) and (3), however, I break up the Internet users into two "generations" (these are Internet years, after all) based on how long they report they have been going online. In column (2), I examine people who have been online two or more years. In column (3), I examine those with less than two years of online experience. The sensitivity is much larger for the experienced Internet users and is significantly different from zero only for that group. The recent adopters have a coefficient one-third the size, though with the large standard error I cannot reject the hypothesis that the coefficients are the same.

TABLE 3

Tax Sensitivity Results, 1997

(1)

(2)

(3)

Full Sample $\quad$ Online $\geq 2$ Years $\quad$ Online $<2$ Years

\begin{tabular}{llll}
\hline $1+t$ & .526 & .897 & .298 \\
& $(.163)$ & $(.309)$ & $(.186)$ \\
$N$ & 24,617 & 8,786 & 15,342 \\
$R^{2}$ & .03 & .04 & .01
\end{tabular}

Notes: Each regression is estimated using weighted least squares as described in the appendix. Each regression includes the following control variables: income, education, age, female, single, children, Asian, nonwhite, Computer at work, home business. Only the coefficient on taxes is reported in order to save space. The dependent variable is the $\{0,1\}$ decision of whether the individual has bought something online. The sample includes all people with Internet access. Column (2) restricts the sample to people who report at least two years of Internet experience at the time of the survey in December of 1997. Column (3) restricts the sample to those with less than two years experience at the time of the survey. The standard errors are in parentheses. 
This pattern could arise for two reasons. First, there could be heterogeneity in the tax sensitivities of the recent adopters and long-time users. This is certainly plausible. Second, though, it is possible that the longer one has access to the Internet, the more sensitive one becomes to tax rates, either from learning or from something else. The distinction could not be more important for public policy.

Under the first case, the growth rate of the Internet will imply that the tax sensitivity gets smaller over time. Each year, essentially, the Internet commerce doubles and the new people added will be inelastic. Under this case, the potential negative effects of raising taxes will disappear quickly.

Under the second case, after people have been online for a short period, they become more price-sensitive. Under this case, the sensitivity of Internet commerce will not fall over time. The negative effects of taxation on commerce will never go away. Indeed, if the growth of the Internet slows, the tax sensitivity may grow because there will no longer be large infusions of price-insensitive customers to dilute the overall sensitivity.

\subsection{Updated Evidence}

The only way to truly distinguish between the two hypotheses would be to have panel data on individual purchases over time. No such data exist. Since the Forrester survey is repeated in December of 1998, however, I can examine the tax sensitivity of customers one year later. If the elasticities are caused by individual effects (i.e., the heterogeneity story), the effect of taxes should be getting noticeably smaller, since the number of new buyers (who are the insensitive customers) is very high in 1998.

In column (1) of Table 4 , I examine the $\{0,1\}$ purchase regression using the 1998 responses as a function of the tax rates and the same demographic variables. Again I report only the tax coefficient [the full results for the baseline specification are listed in column (2) of Table 9]. The results indicate that the effect of taxes is again positive and significant with almost identical point estimates on the probability of buying. The baseline probability of buying has risen in the second sample, so the elasticity here, at 1.2 , is smaller than before.

Since the dependent variable in column (1) is whether the individual has ever purchased something online and may potentially overlap with the results from the previous year, I repeat the specification in column (2), using as the dependent variable the $\{0,1\}$ variable of whether the individual has bought something in the last three months. The results are almost identical in level terms, but the tax elasticity is higher in the last three months than in the longer data because the baseline probabil- 
TABLE 4

Tax Sensitivity Results, 1998

(2)

(1)
(3)

Online
(4)

(5)

\begin{tabular}{|c|c|c|c|c|c|}
\hline & Full sample & last $3 \mathrm{mo}$. & $<1$ year & $1-3$ years & $\geq 3$ years \\
\hline $1+t$ & $\begin{array}{l}.488 \\
(.159)\end{array}$ & $(150)^{.491}$ & $\begin{array}{l}.104 \\
(.283)\end{array}$ & $\begin{array}{c}.553 \\
(.239)\end{array}$ & $\begin{array}{c}.902 \\
(.290)\end{array}$ \\
\hline $\begin{array}{l}N \\
R^{2}\end{array}$ & $\begin{array}{l}35,959 \\
.04\end{array}$ & $\begin{array}{c}35,959 \\
.04\end{array}$ & $\begin{array}{l}8,815 \\
.01\end{array}$ & $\begin{array}{l}16,316 \\
.02\end{array}$ & $\begin{array}{l}10,170 \\
.03\end{array}$ \\
\hline
\end{tabular}

Notes: Each regression is estimated using weighted least squares as described in the appendix. Each regression includes the following control variables: income, education, age, female, single, children, Asian, nonwhite, computer at work, home business. Only the coefficient on taxes is reported in order to save space. The dependent variable in all columns except column (2) is the $\{0,1\}$ decision of whether the individual has bought something online. In column (2) it is the $\{0,1\}$ of whether the individual has bought something in the last three months. The full sample includes all people with Internet access. Column (3) restricts the sample to people who report at least three years of Internet experience at the time of the survey in December of 1998. Column 4 restricts the sample to those with between one and three years of online experience at the time of the survey. Column 5 restricts the sample to those with less than one year of experience at the time of the survey. Standard errors are in parentheses.

ity is lower (elasticity here is 1.5). So as not to miss purchases in the other nine months of the year and to remain comparable with the results from 1997, I will use the complete buying history rather than the last three months.

These results, then, suggest that Internet commerce is still highly sensitive to price and that applying taxes would reduce online commerce significantly.

\subsection{The Anatomy of a Rising Tax Response}

In columns (3)-(5) of Table 4, I break the Internet users in the later sample into three groups: those who have been online at least three years (the same as the group that had been online two years in the earlier sample), those who have been online between one and three years (the same as the group online less than two years in the earlier sample), and those who have been online less than one year (and were thus not represented in the earlier sample). The disaggregated results explain the persistence of high tax sensitivity. In column (3), the long-time Internet users have almost exactly the tax coefficient they had in the previous sample-about .9 and significant. In column (5), the users with less than one year of online experience (who were not represented in the previous survey) have a negligible tax sensitivity that is not significant. In between, however, in column (4), the group that previously had an insignificant tax sensitivity of .298 is now almost twice as responsive at .553 , 
and that sensitivity is significantly different from zero. These results may suggest that individuals are learning about the interaction of the tax code with Internet commerce over time and thus getting more sensitive the longer they are online [columns (3) and (4) of Table 9 give the full results of the two regressions].

One potential alternative explanation for this finding is that novice users show little tax sensitivity simply because they don't buy anything online. This would mean that in both tables, the tax coefficients on novice users are unidentified. This does not seem to be the case in the Forrester data, however. In the 1997 survey, about 16 percent of users with less than two years experience had, in fact, bought something (compared with 21 percent overall). In the 1998 survey, of the novice group (up to one year of online experience) about 24 percent had bought online. For the previous novice group (now with one to three years experience), 44 percent had bought online.

There are purchases; they just don't seem to be greater for people facing higher tax rates among this group. The tax sensitivity of this group of the former Internet novices (now with one to three years of experience) appears to have risen substantially over the intervening year, suggestive of people learning about the tax code over time. This conclusion, however, relies on the repeated cross-sectional data being an accurate pseudo-panel. Before concluding anything from the estimated increase in sensitivity, it is important to get a better sense of whether this group of people that is supposed to be the same in the two surveys does, in fact, look the same. It is not possible to answer this definitively, but it is possible to look at the observable characteristics for the two groups. If they are similar, this may suggest that tax sensitivity grows as individuals learn about the tax code. If they are different, this may suggest that unobserved heterogeneity in the two samples explains the differences.

I present summary statistics of the groups over time in Table 5. The first two columns track the experienced users in 1997 and then in 1998. Columns (3) and (4) track the novice users. In general, the data look quite similar for each group across time. In columns (1) and (2), for example, the data show that the education rates, racial demographics, gender, share of people with children, and use of a computer at work are very similar in the groups that are meant to be the same across time. More importantly, columns (3) and (4) show a similar pattern for the formerly novice users. In almost all categories they look quite similar in the two samples, except that the share of individuals that are single is somewhat lower in the later sample (.38 versus .31 ).

Table 6 examines the geographic distribution of the novice users over 
TABLE 5

Comparison Summary of Statistics by Group and Over Time(a)

\begin{tabular}{lcccc}
\hline & $\begin{array}{c}\text { Online } \\
\geq 2 \text { yrs } \\
1997\end{array}$ & $\begin{array}{c}\text { Online } \\
\geq 3 \text { yrs }\end{array}$ & $\begin{array}{c}\text { Online } \\
<2 \text { yrs } \\
1998\end{array}$ & $\begin{array}{c}\text { Online } \\
1-3 \text { yrs } \\
1997\end{array}$ \\
\hline$N$ & 9,837 & 10,675 & 16,298 & 17,149 \\
Income & $60.6(34.8)$ & $65.1(33.8)$ & $54.7(32.2)$ & $64.1(31.7)$ \\
Education & $15.3(2.2)$ & $15.4(2.2)$ & $14.6(2.3)$ & $14.9(2.3)$ \\
Age & $39.7(12.5)$ & $42.0(12.4)$ & $40.4(12.4)$ & $43.4(12.0)$ \\
Female & $.62(.49)$ & $.61(.49)$ & $.52(.50)$ & $.54(.50)$ \\
Single & $.42(.49)$ & $.39(.49)$ & $.38(.49)$ & $.31(.46)$ \\
Children & $.35(.48)$ & $.34(.47)$ & $.44(.50)$ & $.42(.49)$ \\
Asian & $.03(.16)$ & $.03(.16)$ & $.02(.13)$ & $.02(.13)$ \\
Nonwhite & $.15(.35)$ & $.13(.33)$ & $.15(.35)$ & $.12(.33)$ \\
Computer at work & $.84(.37)$ & $.83(.37)$ & $.75(.43)$ & $.77(.42)$ \\
Home business & $.18(.39)$ & $.22(.41)$ & $.17(.37)$ & $.20(.40)$ \\
Bought online & $.31(.46)$ & $.64(.48)$ & $.16(.37)$ & $.44(.50)$ \\
\hline
\end{tabular}

Source: Author's calculations using data from Forrester Research.

(a) Standard deviations in parentheses.

time. In both years, the top eight states are the same and their share of the total sample is listed in the top panel of the table. There is a moderate increase in the share of people living in California (from 10.4 to 12.1 percent), but other than that, the state distribution remains quite similar. The bottom panel lists the distribution across census regions. Here they sum to 100 percent. There is a moderate shift from North Central states to Pacific and Mountain states, but again the geographic distributions are fairly similar across time.

From these statistics, I conclude that the groups in the two samples probably are fairly good representations of the same people and will attribute the changes in tax sensitivity across time to actual changes in the behavior and learning of the group rather than to heterogeneity across the samples.

\subsection{The Generation Gap}

I examine the rise in tax sensitivity a bit further in Tables 7 and 8 . In them I break up the groups by both the time they have been online and by age, and follow what happens to the tax sensitivities of each ageexperience cell from 1997 to 1998 . Because the age data are in block form (reported age between 20 and 25, for example), I have to decide how to age the two groups. I choose as the cutoff those under age 35 in the early sample and under 40 in the later sample, because with aging some 
TABLE 6

Geographic Distribution of 1997 Novice Users

Percentage of total sample

Online 1-3 years in $1998 \quad$ Online < 2 years in 1997

Top eight states

California

Texas

New York

Florida

Pennsylvania

Illinois

Ohio

Michigan

By region

South Atlantic

Pacific

East North Central

Mid-Atlantic

West Southern

West North Central

Mountain

New England

East Southern
12.1

7.3

6.7

6.0

4.4

4.2

4.1

3.4

19.4

15.8

15.7

14.3

10.5

7.0

6.7

5.4

5.2
10.4

7.1

6.6

6.1

4.6

4.4

4.3

3.8

Source: Author's calculations using data from Forrester Research.

TABLE 7

Anatomy of the Tax Elasticity, 1997

(1)

Online $\geq 2 \mathrm{yr}$ Age $\geq 35$

(2)

Online $\geq 2 \mathrm{yr}$ Age $<35$

(3)

Online $<2$ yr Age $\geq 35$

(4)

18.8

13.8

16.9

14.0

11.3

7.4

6.4

4.6

6.8

\begin{tabular}{lllll} 
& Age $\geq 35$ & Age $<35$ & Age $\geq 35$ & \multicolumn{1}{c}{ Age $<35$} \\
\cline { 2 - 3 } $1+t$ & .927 & .837 & .275 & .347 \\
& $(.398)$ & $(.489)$ & $(.232)$ & $(.310)$ \\
$N$ & 5,305 & 3,481 & 9,770 & \\
$R^{2}$ & .03 & .06 & .01 & 5,572 \\
\hline
\end{tabular}

Notes: Each regression is estimated using weighted least squares as described in the appendix. Each regression includes the following control variables: income, education, age, female, single, children, Asian, nonwhite, computer at work, home business. Only the coefficient on taxes is reported in order to save space. The dependent variable is the $\{0,1\}$ decision of whether the individual has bought something online. Each regression restricts the sample to people described in the second row at the top of the column, based on their age and Internet experience at the time of the survey in December of 1997. Standard errors are in parentheses. 


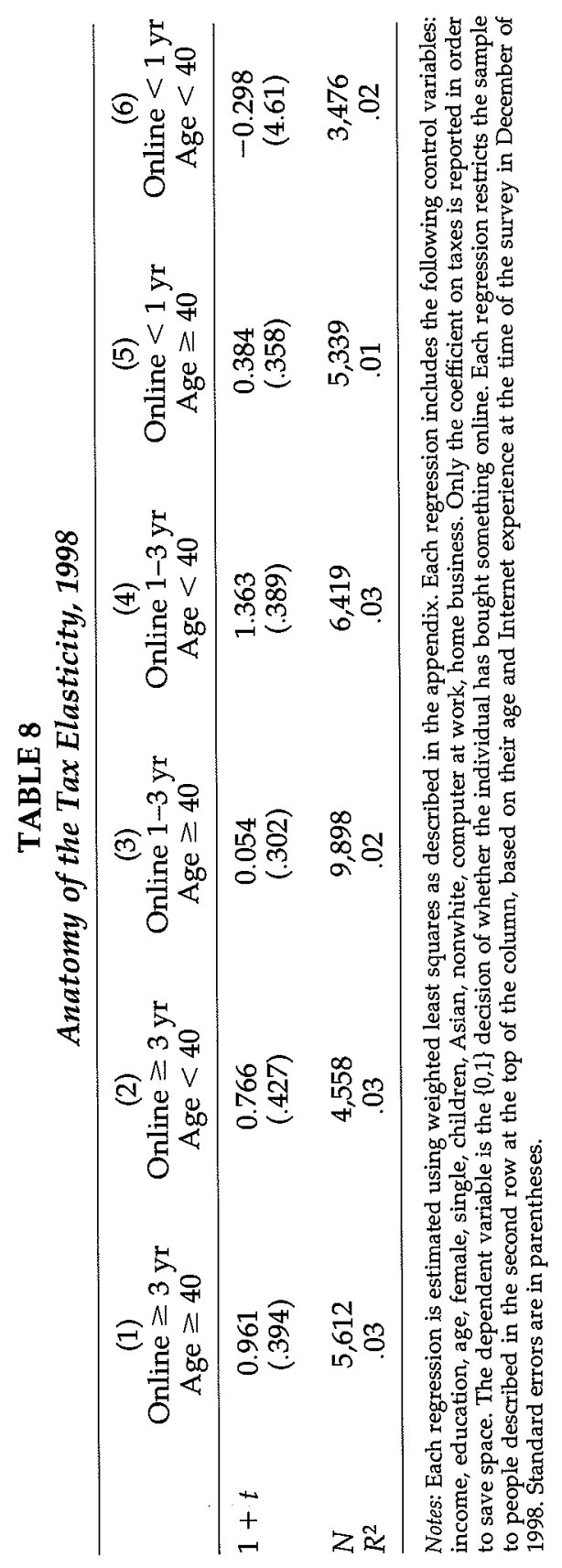


people move in to the higher group, and the age histograms suggest that a disproportionate share of the 30-to-35 group in 1997 moved into the 35to-39 in 1998. Using under 35 for both samples and ignoring the rising age of the population did not change the qualitative results.

Columns (1) and (2) of Table 7 show the sensitivity of old and young users with less than two years of online experience in December of 1997. Both elasticities are insignificant and small. Columns (3) and (4) look at old and young users with more than two years of online experience in December of 1997. Both coefficients here are large and significantly different from zero. In these data, the responses of the two age groups look very similar and comport with the aggregate results listed above.

In Table 8, however, I repeat this exercise but for the three online experience groups in December of 1998 (again assuming that the composition of the groups remains the same). In columns (1) and (2), the old and the young with more than three years of experience in December of 1998 show large and significant coefficients very similar to their magnitudes in Table 7. In the previous sample they were people with at least two years of online experience. On the other side, in columns (5) and (6), the brand-new users show no significant tax sensitivity in either age group. The novice users who are young even have a point estimate that is negative. These groups have no comparison coefficient in 1997, because they were not yet online.

In between, in columns (3) and (4), I examine the groups with 1 to 3 years of Internet experience in December of 1998. These are the groups that were novice users in Table 7 having less than two years of online experience. In the 1997 survey they had small and insignificant tax sensitivities. In column (3), the results verify that for people over 40 there is still a small and insignificant tax coefficient. The entire change in the elasticity of the middle group documented above is due to a dramatic rise in tax sensitivity among the group in column (4)-those under 40 with one to three years of Internet experience. In 1997, this group had a tax coefficient of .347 that was not significant. In 1998 it is four times higher, at 1.36 , and is very significant. ${ }^{8}$

This result is consistent with the hypothesis that the young are the fastest learners about new technology and that being around others who are buying things tax-free has a faster effect on them. Goolsbee and Klenow (1998) have shown that there are important local spillovers in

8 Note that a rising price sensitivity is not the same thing as an increase in spending. To say that this group became more tax-sensitive means that, if spending was growing, it grew most in places with lower taxes. 
the diffusion of home computers and the Internet and that these spillovers are largest for the young. Goolsbee and Zittrain (1999) suggest that such spillovers may extend to Internet commerce. If this result generalizes, and young people's tax sensitivity tends to rise over time as they learn about the Internet and the tax code, the negative effects of imposing taxes on Internet commerce are unlikely to go away as the Internet grows. As the number of users rises, the current and future young will become increasingly important as a share of the total Internet user base. Unless their price responsiveness falls as they age, the trade-off between taxes and Internet commerce will continue.

\section{Conclusion}

The explosion of Internet commerce has generated continued interest in the effects that tax policy has on individuals' online buying decisions. The results in this paper show that new Internet users seem to have little sensitivity to taxes. Yet despite the rapid growth in the number of new users, the overall tax sensitivity of Internet commerce remains high. The explanation is that as new users, particularly people younger than 40 , gain experience and learn about the tax code, their tax sensitivity rises substantially. So long as this continues, the sensitivity of Internet commerce to tax rates will remain.

\section{APPENDIX: DATA}

The online purchase data come from a proprietary survey conducted by Forrester Research, a leading market research company whose specialty is the information economy. The first survey was conducted by the NPD group in December of 1997 as part of Forrester's Technographics 98 program. The second survey was conducted by NPD in December of 1998 as part of Technographics 99 . Both surveys were conducted by mail and received a large number of respondents. The first has data on more than 110,000 U.S. households, the second on more than 85,000 .

Though the sampling methodology is not public, the survey is meant to be nationally representative [more details on the Technographics data can be found in Bernoff et al. (1998) and Goolsbee (2000)]. Its purpose is to provide technology, communications, and consumer marketing companies with information for evaluating the consumer segments for their products. The Forrester data are widely respected in the industry, and private-sector companies pay significant amounts of money to get access to them. The geographic distribution, however, is 
not directly proportional to the television market populations, so in the results I weight each observation by the population per survey respondent, measured by matching the data to the population figures given in Nielsen (1999).

The survey asks adults about their household characteristics. The variables I use here include geographic location, income, education, age, gender, marital status, race, whether they have children, whether they use a computer at work, and whether they run a business from home. I turned the series of dummy variables for education, age, and income into continuous variables. If income was stated as between 35 and 40 thousand dollars, for example, I imputed an income of 37.5 thousand. For top-coded variables, I tried various values, and the choices had almost no effect on the results. Neither did including dummies rather than converting the observables into continuous variables.

Respondents were also asked whether they have access to the Internet and, if so, how long they have been online, whether they have bought something online, and so on. Only people with online access are asked about their online buying habits, and the number of people with access rose substantially over the year. This yields approximately 25,000 households in the earlier sample and approximately 37,000 in the later sample that I use in the results of this paper. I take these households to be representative of online households, but there is no way to verify this independently.

Matching the purchase data to local sales-tax rates is complicated by the fact that the data do not give the town name, only the state and metropolitan area. Many states have constant rates in all cities. For states without uniform rates across cities, I assume that anyone living in the primary state of the metropolitan area (defined by television market) resides in the area's major city. As an example, I classify people in the Chicago area who reside in Illinois as being in Chicago itself. This prevents me from distinguishing between city and suburb within the same state, but is necessary given the nature of the data. I classify people living in a different state as being in the largest city in the closest county to the primary city (measured by Rand McNally, 1997). The tax rates for each location were compiled either from direct conversation with the department of revenue in the state or from documents on the department's Web site. For states without centralized information, I contacted a local chamber of commerce in the city or county. The results do not include individuals who either do not reside in a television market or fail to report their market in the survey.

The full regression results are given in Table 9. 


\section{TABLE 9}

Full Regression Results

\begin{tabular}{|c|c|c|c|c|}
\hline $\begin{array}{l}\text { Independent } \\
\text { Variable }\end{array}$ & $\begin{array}{c}(1) \\
\text { Baseline, } \\
1997\end{array}$ & $\begin{array}{c}(2) \\
\text { Baseline, } \\
1998\end{array}$ & $\begin{array}{c}(3) \\
\text { Online }<2 \text { yrs, } \\
1997\end{array}$ & $\begin{array}{c}(4) \\
\text { Online } 1-3 \text { yrs, } \\
1998\end{array}$ \\
\hline $1+t$ & $\begin{array}{c}.5261 \\
(.1629)\end{array}$ & $\begin{array}{c}.4882 \\
(.1597)\end{array}$ & $\begin{array}{l}.2984 \\
(.1859)\end{array}$ & $\begin{array}{l}.5529 \\
(.2387)\end{array}$ \\
\hline Income & $\begin{array}{c}.0008 \\
(.0001)\end{array}$ & $\begin{array}{c}.0009 \\
(.0001)\end{array}$ & $\begin{array}{c}.0003 \\
(.0001)\end{array}$ & $\begin{array}{c}.0008 \\
(.0001)\end{array}$ \\
\hline Education & $\begin{array}{l}.0068 \\
(.0012)\end{array}$ & $\begin{array}{l}.0145 \\
(.0012)\end{array}$ & $\begin{array}{c}.0047 \\
(.0014)\end{array}$ & $\begin{array}{c}.0069 \\
(.0018)\end{array}$ \\
\hline Age & $\begin{array}{c}-.0019 \\
(.0002)\end{array}$ & $\begin{array}{c}-.0042 \\
(.0002)\end{array}$ & $\begin{array}{c}-.0007 \\
(.0003)\end{array}$ & $\begin{array}{c}-.0036 \\
(.0004)\end{array}$ \\
\hline Female & $\begin{array}{l}.0761 \\
(.0053)\end{array}$ & $\begin{array}{c}.0746 \\
(.0053)\end{array}$ & $\begin{array}{c}.0334 \\
(.0061)\end{array}$ & $\begin{array}{l}.0516 \\
(.0079)\end{array}$ \\
\hline Single & $\begin{array}{c}.0330 \\
(.0064)\end{array}$ & $\begin{array}{c}.0695 \\
(.0063)\end{array}$ & $\begin{array}{c}.0148 \\
(.0072)\end{array}$ & $\begin{array}{c}.0694 \\
(.0096)\end{array}$ \\
\hline Children & $\begin{array}{l}-.0334 \\
(.0058)\end{array}$ & $\begin{array}{c}-.0428 \\
(.0058)\end{array}$ & $\begin{array}{c}-.0190 \\
(.0065)\end{array}$ & $\begin{array}{c}-.0257 \\
(.0087)\end{array}$ \\
\hline Asian & $\begin{array}{l}.0205 \\
(.0184)\end{array}$ & $\begin{array}{c}.0577 \\
(.0186)\end{array}$ & $\begin{array}{c}-.0042 \\
(.0237)\end{array}$ & $\begin{array}{l}.0420 \\
(.0292)\end{array}$ \\
\hline Nonwhite minority & $\begin{array}{l}-.0112 \\
(.0074)\end{array}$ & $\begin{array}{c}-.0266 \\
(.0078)\end{array}$ & $\begin{array}{c}-.0075 \\
(.0085)\end{array}$ & $\begin{array}{c}-.0177 \\
(.0119)\end{array}$ \\
\hline Computer at work & $\begin{array}{c}.0229 \\
(.0066)\end{array}$ & $\begin{array}{c}.0136 \\
(.0066)\end{array}$ & $\begin{array}{c}.0047 \\
(.0072)\end{array}$ & $\begin{array}{c}-.0129 \\
(.0098)\end{array}$ \\
\hline Home business & $\begin{array}{c}.0640 \\
(.0069)\end{array}$ & $\begin{array}{c}.0764 \\
(.0065)\end{array}$ & $\begin{array}{c}.0416 \\
(.0080)\end{array}$ & $\begin{array}{c}.0707 \\
(.0097)\end{array}$ \\
\hline Constant & $\begin{array}{c}-.4872 \\
(.1743)\end{array}$ & $\begin{array}{c}-.2390 \\
(.1709)\end{array}$ & $\begin{array}{l}-.2395 \\
(.1988)\end{array}$ & $\begin{array}{c}-.1899 \\
(.2553)\end{array}$ \\
\hline $\begin{array}{l}N \\
R^{2}\end{array}$ & $\begin{array}{c}24,617 \\
.027\end{array}$ & $\begin{array}{l}35,959 \\
.0375\end{array}$ & $\begin{array}{l}15,342 \\
.008\end{array}$ & $\begin{array}{c}16,316 \\
.0199\end{array}$ \\
\hline
\end{tabular}

Notes: These are the full results of some of the regressions reported in the tables above. Column (1) comes from column (1) of Table 3. Column (2) comes from column (1) of Table 4. Column (3) comes from column (3) of Table 3 . Column (4) comes from column (4) of Table 4 . The notes to those tables contain details for each of the regressions. Standard errors are in parentheses. 


\section{REFERENCES}

Andal, Dean F. (1997). "State and Local Taxation of Electronic Commerce: Read My E-mail, No New Taxes," presented at the symposium on Multi-jurisdictional Taxation of Electronic Commerce, Harvard Law School, Cambridge, MA, April 5, 1997. State Tax Notes 12(no. 18):1387-1395.

Bailey, Joseph (1998). "Intermediaries and Electronic Markets: Aggregation and Pricing in Internet Commerce." Department of Management and Policy, Massachusetts Institute of Technology. Fh.D. Dissertation.

Bernhoff, Josh, Shelley Morrisette, and Kenneth Clemmer (1998). "Technographics Service Explained." Forrester Report 1(no. 0).

Besley, Tim, and Harvey Rosen (1999). "Sales Taxes and Prices: An Empirical Analysis." National Tax Journal LII:157-178.

Braid, Ralph (1987). "The Spatial Incidence of Retail Sales Taxes." Quarterly Journal of Economics CII:881-891.

Brynjolfsson, Erik, and Michael Smith (1999). "Frictionless Commerce? A Comparison of Internet and Conventional Retailers." MIT Sloan School of Management. Mimeo.

Economist, The (1997). "Taxes Slip through the Net." May 31, p. 22.

Fox, William (1986). "Tax Structure and the Location of Economic Activity along State Borders." National Tax Journal XIV:362-374.

Fox, William and Matthew Murray (1997). "The Sales Tax and Electronic Commerce: So What's New?" National Tax Journal 50(no. 3):573-592.

Goldman Sachs, 1997. "Cyber Commerce: Internet Tsunami." Corporate Report, August. New York.

Goolsbee, Austan (2000). "In a World without Borders: The Impact of Taxes on Internet Commerce." Forthcoming in Quarterly Journal of Economics.

Goolsbee, Austan, and Peter Klenow (1999). "Evidence on Learning and Network Externalities in the Diffusion of Home Computers." University of Chicago, Graduate School of Business. NBER Working Paper no. 7329.

Goolsbee, Austan, and Jonathan Zittrain (1999). "Evaluating the Costs and Benefits of Taxing Internet Commerce." National Tax Journal LII(no. 3):413-428.

Gordon, Roger (1983). "An Optimal Taxation Approach to Fiscal Federalism." Quarterly Journal of Economics XCIIX:567-586.

Gordon, Roger, and Soren Nielsen (1997). "Tax Evasion in an Open Economy: Value-Added vs. Income Taxation." Journal of Public Economics LXVI:173-197.

Graham, Robert (1999). "Should the Internet Be Taxed? Communities Hurt if the Web Isn't Taxed." Roll Call, February 22.

Hellerstein, Walter (1997a). "Telecommunications and Electronic Commerce: Overview and Appraisal." State Tax Notes 12(no. 7):519-526.

Hellerstein, Walter (1997b). "Transactions Taxes and Electronic Commerce: Designing State Taxes that Work in an Interstate Environment." National Tax Journal 50(no. 3):593-606.

Hellerstein, Walter (1997c). "State Taxation of Electronic Commerce: Preliminary Thoughts on Model Uniform Legislation," presented at the Symposium on Multi-jurisdictional Taxation of Electronic Commerce, Harvard Law School, Cambridge, MA, April 5. State Tax Notes, 12(no. 17):1315-1324.

Holmes, Thomas (1998). "The Effect of State Policies on the Location of Manufacturing: Evidence from State Borders." Journal of Political Economy CVI:667-705. 
Horner, Frances, and Jeffrey Owens (1996). "Tax and the Web: New Technology, Old Problems." International Bureau of Fiscal Documentation Bulletin, November/ December:516-523.

Kanbur, Ravi, and Michael Keen (1993). "Jeux sans Frontières: Tax Competition and Tax Coordination when Countries Differ in Size." American Economic Review LXXXIII:877-892.

Mackie-Mason, Jeffrey, and Hal Varian (1995). "Pricing the Internet." In Public Access to the Internet, Brian Kahin and James Keller (eds.). Cambridge, MA: MIT Press.

McKnight, Lee and Joseph Bailey (1997). Internet Economics. Cambridge, MA: MIT Press.

McLure, Charles (1997). "Electronic Commerce, State Sales Taxation, and Intergovernmental Fiscal Relations." National Tax Journal 50(no. 4):731-750.

McLure, Charles (1998). "Achieving a Level Playing Field for Electronic Commerce: Policy Considerations." State Tax Notes 14:1767-1784.

McQuivey, James, Kate Delhagen, Kip Levin, and Maria LaTour Kadison (1998). "Retail's Growth Spiral." The Forrester Report 1(no. 8).

Mikesell, John (1970). "Central Cities and Sales Tax Rate Differentials: The Border City Problem." National Tax Journal XXIII:206-213.

Mintz, Jack, and Henry Tulkens (1986). "Commodity Tax Competition between Member States of a Federation: Equilibrium and Efficiency." Journal of Public Economics XXIX:133-172.

Murray, Matthew (1997). "Telecommunications Services and Electronic Commerce: Will Technology Break the Back of the Sales Tax?" State Tax Notes, 12:272-280.

Newman, Nathan (1995). "Prop 13 Meets the Internet: How State and Local Government Finances are Becoming Road Kill on the Information Superhighway." Center for Community Economic Research, University of California, Berkeley. Mimeo.

Nielsen Media Research (1999). "Designated Market Areas." 〈http://www .nielsenmedia.com/whatratingsmean/dmas.html $\rangle$. Access date September 9.

Poterba, James (1996). "Retail Price Reactions to Changes in State and Local Sales Taxes." National Tax Journal XCIX:165-176.

Rand McNally (1997). Road Atlas: United States, Canada, Mexico (deluxe edition). Skokie, IL: Rand McNally.

Rappaport, Neal (1994). Applied Econometric Essays on Sales Taxes and Computer Price Indices. MIT Ph.D. Dissertation.

Sheppard, Doug (1998). "Representatives of Cities, Software Publishers Square Off on Internet Taxation." State Tax Notes 15(no. 941).

Smith, Robert (1999). "American Consumers Can't Afford Another Tax." Roll Call, February 22.

Steele, Thomas H., and Walter Hellerstein (1994). "State and Local Taxation of the Information Highway." National Tax Association, Proceedings of the 86th Annual Conference, Charleston, SC, pp. 221-225.

Stephenson, Jack, and Michael Zeisser (1998). "Don't Tax the Internet-Yet." Wall Street Journal, June 6.

Trandel, Gregory (1992). "Evading the Use of Tax on Cross-Border Sales: Pricing and Welfare Effects." Journal of Public Economics 35:333-354.

Trandel, Gregory (1994). "Interstate Commodity Tax Differentials and the Distribution of Residents." Journal of Public Economics LIII:435-457. 
Walsh, Michael, and Jonathan Jones (1988). "More Evidence on the 'Border Tax' Effect: The Case of West Virginia." National Tax Journal XIV:362-374.

Wyden, Ron (1997). "Statement on the Internet Tax Freedom Act." Homepage of the United States Senate. (http://www.senate.gov/ wyden/leg/cybstate.htm〉. Access date, November 10, 1998. 
